\title{
How to BE Well SHOD TO ABSORB SHOCKS? SHOCK SYNCHRONIZATION AND JOINING THE EURO ZONE
}

\author{
NATACHA GILSON \\ CESIFO WORKING PAPER NO. 1878 \\ CATEGory 6: MONETARy POLICY AND INTERNATIONAL FinANCE \\ DECEMBER 2006
}

An electronic version of the paper may be downloaded

- from the SSRN website:

www.SSRN.com

- from the RePEc website:

www.RePEc.org

- from the CESifo website:

www.CESifo-group.de 


\title{
How to BE Well SHOD TO ABSORB SHOCKS? SHOCK SYNCHRONIZATION AND JOINING THE EURO ZONE
}

\begin{abstract}
This paper examines the demand and supply shocks observed in the present Eurozone member states and those observed in some neighboring countries. The analysis is based on recent data and each Eurozone member country is compared with an aggregate series corresponding to an area made up of the entire Eurozone minus the country being compared. The results of the study confirm that, even when the series are corrected by removing the country being compared, the disturbances observed in large Eurozone countries are well correlated with the disturbances observed in other Eurozone member countries.
\end{abstract}

JEL Code: E42, F31, F33.

Keywords: shocks, Eurozone, optimal currency area.

\author{
Natacha Gilson \\ Department of Economics and Sociology \\ Arpege Unit of Economic Research \\ 151, chaussée de Binche \\ 7000 Mons \\ Belgium \\ gilson@fucam.ac.be
}

November 2006

The author warmly thanks Konstantin Kholodilin for the valuable comments given on a previous version of this paper and gratefully acknowledges the organizers and participants of the CESifo conference on "Euro-Area Enlargement" held in Munich on 24 November 2006. 


\section{Introduction}

The ten countries, which entered the European Union on the $1^{\text {st }}$ of May 2004, are expected to adopt the Euro when they will be ready to do so. While the new member states seemed enthusiastic about the possibility to enter in the Euro area once they joined the European Union, the International Herald Tribune reported recently that currently "Euro is losing its sparkle among new EU members". ${ }^{1}$

Why did some countries decide to enter in the Euro area while others preferred not to enter? Why did some EU15 member countries (Denmark, Sweden and the United Kingdom) decide to stay out? Why did some Italian ministers complain, in June 2005, about the previous decision to join EMU? ${ }^{2}$ What will be the future attitudes of the new EU member states with respect to the promptness of their Euro adoption?

On the $16^{\text {th }}$ of June, the European Council officially welcomed the Commission's proposal that Slovenia should adopt the Euro on 1 January 2007 as Slovenia fulfilled all the convergence criteria set out in the Treaty. ${ }^{3}$

A report on the practical preparations for the future enlargement of the Euro area, published in June 2006 by the European Commission, summarizes the preparation process in the other new European member states. ${ }^{4}$ Initially, the target date of entry in the Euro zone for Estonia and Lithuania was fixed on 1 January 2007. But the Estonian government decided on 27 April 2006 to postpone its target date to 1 January 2008 as it became apparent that Estonia would not be able to comply with the Maastricht convergence criteria in time. In Lithuania, the Commission's Convergence Report, which was adopted on 16 May 2006, concluded that the inflation target of the Maastricht criteria was not fulfilled. Consequently, the Euro will not be introduced in Lithuania on the date which was originally aimed at by the government. Cyprus, Latvia and Malta planned initially to adopt the Euro on 1 January 2008, the Slovak Republic on 1 January 2009, the Czech Republic and Hungary on 1 January 2010. The target dates of these countries are unchanged. Finally, Poland has not yet decided to adopt the Euro.

It is important to underline that national target dates are objectives fixed by the national governments, while the final decisions on entry in the Euro zone are taken by the Council, meeting at Head of State and Government level. The latter reaches a decision after examining the convergence reports submitted by the Commission and the European Central Bank and consulting the European Parliament. It decides, on a qualified-majority basis and on a proposal from the Commission, which Member States meet the necessary conditions to adopt the single currency on the basis of the criteria laid down in Article 121. Once this decision has been taken, the Council sets the irrevocable conversion rate between the national currency in question and the Euro. This decision is taken

\footnotetext{
${ }^{1}$ Cf. The International Herald Tribune on Tuesday February 14, 2006.

${ }^{2}$ In June 2005, two Italian Ministers cast doubt on Italy keeping the Euro, and called for the return of the lira.

${ }^{3}$ Actually, the decision on the entry of the new EU member states into the Euro zone is based on the fulfillment of the convergence criteria. These criteria, often named the Maastricht criteria, which are the same as those which were applied to decide on the accession of the current Euro zone member states, are presented in Article 121(1) of the Treaty establishing the European Community.

${ }^{4}$ See http://ec.europa.eu/economy finance/euro/documents/comm2006 322final_en.pdf
} 
unanimously by those Member States which have adopted the Euro and the Member State in question. ${ }^{5}$

The Optimum Currency Area (OCA) is a natural starting point to analyze the rumors of leaving a monetary union or the issue of joining it. This strand of literature develops the criteria that should be respected when countries or regions decide to share the same currency. The symmetry of the disturbances striking economies (or regions) is one of the criteria highlighted by the OCA theory. This theory arose in the 1960s and generated a broad strand of literature which highlighted the conditions that would have to be fulfilled in order to determine whether a country (or a region) should join a currency area or not. This literature has been built on the seminal work of Mundell (1961), who was a pioneer in this area. ${ }^{6}$ More recently, Bayoumi (1994) presented a model of optimal currency areas with microeconomic foundations to support Mundell's original thesis. In this work, he stressed that the conditions for an OCA are that members of the currency union should experience symmetric shocks. This is due to the fact that, in participating in a monetary union, the member countries relinquish their ability to determine their own monetary policy. In a monetary union, a single monetary policy is defined for the whole currency union by a common central bank. When asymmetric disturbances strike the member countries, a common monetary policy cannot be used as an adjustment mechanism, whereas if the countries had not been in a monetary union, each country would have been free to use its national monetary policy to adjust to the asymmetric disturbance. For instance, a loose monetary policy would reduce the decline in output in a country affected by a negative demand shock, a tight monetary policy would reduce the increase in prices in a country affected by a negative supply shock and a tight monetary policy would reduce the price rise in a country struck by a positive demand shock. Whereas in a currency union, a single monetary policy cannot adjust to disturbances that differently affect the prices or output of the member countries.

Optimum currency area theory stresses that a group of countries hit by asymmetric disturbances could nevertheless optimally form a currency area when possible alternative adjustment mechanisms exist in those countries. However, in the absence of alternative adjustment mechanisms, countries (or regions) may still optimally form a currency area if the disturbances striking them tend to be symmetric. This means that countries that are subject to similar economic cycles and shocks can share the same monetary policy and use the same currency. ${ }^{7}$

The criterion of the symmetry of shocks will be the recurrent theme of this paper whose the main overall content is the measure of demand and supply shocks observed in the actual Euro area member countries and in several neighboring countries.

Nevertheless, before going further, it is important to stress two important points. Firstly, countries belonging to a monetary union should rely on other shock absorber

\footnotetext{
${ }^{5}$ The complete procedure can be found on http://europa.eu/scadplus/leg/en/lvb/125066.htm

${ }^{6}$ A recent survey of the OCA theory can be found in Mongelli (2002) and in De Grauwe (2003a).

${ }^{7}$ This does not mean that countries struck by similar shocks will necessarily share the same currency. But in the event of symmetric shocks, such countries could share the same currency without problems because a single monetary policy would adjust in a similar way to the disturbances simultaneously striking the countries.
} 
mechanisms, as currency unions may suffer at times from asymmetric shocks. Consequently, in reading the pages below, it is important to keep in mind that the detection of some asymmetries among countries participating or planning to participate in a currency area does not necessarily mean that this currency area is not viable as shocks can also be absorbed by other adjustment mechanisms. In fact, the detection of symmetric shocks simply means that the common monetary policy will be able to absorb these symmetric shocks and that the cost of relinquishing the exchange rate is rather low. Secondly, when countries are struck by identical shocks, exchange rate adjustment is not the appropriate response as these countries will try to simultaneously modify their exchange rate in the same way which is unsuccessful. Moreover, one could a priori believe that enlargement will lead to an increase in the occurrence of asymmetric shocks inside the EU. A rationale for this fear could be based on the following reasoning: let us assume that a currency area is made up of 2 countries and that each country could be either in a state of expansion or in a state of recession. This means that 4 combinations of states could be observed and that half of these combinations are asymmetric. Let us now assume that a currency area is made up of 12 countries. Then applying the same reasoning, 4,096 combinations of states could be observed with 4,094 of them asymmetric for at least one country. Finally, if the currency area is made up of 25 countries, 33,554,432 combinations of states could be observed with 33,554,430 which are asymmetric for at least one country. According to this reasoning, each new accession in the Euro zone could jeopardize the stability of the European monetary union because an undifferentiated monetary policy will not be suitable for all its members. Of course, this presentation of the occurrence of asymmetric shocks is too simple because it completely ignores the possibility to use national budgetary policies to adjust the shocks ${ }^{8}$ and the size of those asymmetries. It is, therefore, important to determine whether European countries are affected by similar disturbances or not. Hence, the rest of this paper is devoted to this issue.

Several studies have been devoted to the analysis of the similarities in the disturbances affecting European countries. Those studies started at the beginning of the 1990s, when the debates about the creation of the European Monetary Union were launched ${ }^{9}$ (see, for example, Bayoumi and Eichengreen (1992); Funke (1997); Ballabriga et al. (1999); and Altavilla (2004)). More recently, due to the enlargement of the EU and the possible future extension of the Euro zone to the new entrants, the same kind of analyses has been performed including the new EU member states (Boone and Maurel (1999); Korhonen and Fidrmuc (2001); Fidrmuc and Korhonen (2003); De Grauwe (2003b); Frenkel and Nickel (2005a) and (2005b)). Fidrmuc and Korhonen (2006) also present a meta-analysis of studies of the business cycle correlation between the Euro area and the Ceecs.

Although some studies on this issue have already been undertaken, it is important to continue to investigate this topic with different kinds of data or with different methodologies in order to confirm the robustness of the results. This is why, in this

\footnotetext{
${ }^{8}$ Of course, in the Euro zone, national budget policies are straitjacketed by the stability and growth pact, but in the new version of the pact a breach of the $3 \%$ deficit rule should be tolerated in the event of a decline in output growth.

${ }^{9}$ Of course, this kind of analysis has also been applied to other groups of countries. See for example Bayoumi and Eichengreen (1994), Bayoumi et al. (1999), Bayoumi and Mauro (2001), or Wyplosz (2001), Zhang and Wan (2005).
} 
paper, this issue is examined by applying the Bayoumi and Eichengreen methodology ${ }^{10}$ to recent data. In fact, the papers cited above, focusing on the future enlargement of the Euro zone, are based on data which are, in all cases, prior to 2002.

The main goal of this paper is to compare the shocks observed in the current Euro zone with the shocks observed in the other EU member states and in some neighboring countries. Of course, as mentioned above, the decision on the entry of the new EU member states into the Euro zone will be based on the fulfillment of the convergence criteria, as it was the case for Slovenia. These criteria are presented in Article 121(1) of the Treaty establishing the European Community and were also applied to decide on the accession of the current Euro zone member states. Nevertheless, for the reasons mentioned above, it is still interesting to examine whether the shocks striking these countries have been similar to those observed in the Euro zone.

The structure of the paper will be as follows: The Bayoumi and Eichengreen methodology, which has been used in this paper to measure demand and supply shocks hitting the Euro zone and the neighboring countries, is explained in section 2. Data are described in section 3. The similarities in contemporaneous correlations of demand and supply disturbances hitting the Euro zone member countries and their neighbors are presented in section 4. Finally, the conclusion is presented in section 5.

\section{Description of the methodology}

The Bayoumi and Eichengreen methodology (which is based on the Blanchard and Quah methodology) allows the economic shocks to be decomposed into supply and demand shocks.

This methodology is based on the AD-AS model. The aggregate demand curve (labeled AD) is downward sloping in the price output plane, the short run aggregate supply curve (SRAS) is upward sloping and the long run supply curve (LRAS) is vertical as depicted in Figure 1.

${ }^{10}$ Which was already applied in some of the papers mentioned above. 


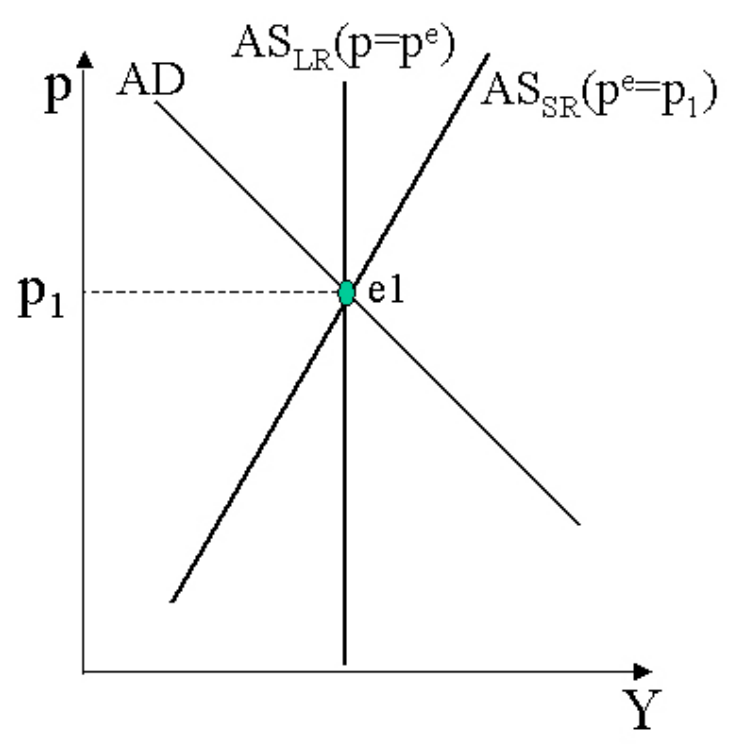

Figure 1

Economic textbooks usually offer a detailed description of this model.

In this AD-AS model, supply shocks result in permanent changes in output while demand shocks have no long run effect on output. Moreover, demand and supply shocks have different effects on prices: positive demand shocks raise prices while positive supply shocks reduce them.

It is possible to identify these two types of shocks and their dynamic effects on output and prices with the help of a structural vector auto-regression model. The Bayoumi and Eichengreen approach determines two kinds of perturbations: shocks that affect the demand curve (for example, due to monetary or fiscal policy changes, or even due to modifications in consumer behavior) and shocks that affect the supply curve (for example, technological change). This methodology extracts from price and output data the underlying demand and supply shocks. Once those supply and demand shocks have been computed for each country, their correlation with the supply and demand of the Euro zone can be measured.

Using a VAR, it is possible to decompose permanent and temporary shocks to a variable. Blanchard and Quah (1989) propose a bi-variate vector autoregressive procedure to separate the current shocks striking output and prices from their dynamic responses to previous shocks. The Bayoumi and Eichengreen methodology is based on the Blanchard and Quah decomposition and assumes that this supply and demand model can be represented by an infinite moving average representation:

$$
\left(\begin{array}{c}
\Delta \mathrm{y}_{\mathrm{t}} \\
\Delta \mathrm{p}_{\mathrm{t}}
\end{array}\right)=\left(\begin{array}{c}
\mathrm{b}_{10} \\
\mathrm{~b}_{20}
\end{array}\right)+\left(\begin{array}{ll}
\mathrm{b}_{11,0} & \mathrm{~b}_{12,0} \\
\mathrm{~b}_{21,0} & \mathrm{~b}_{22,0}
\end{array}\right)\left(\begin{array}{l}
\varepsilon_{\mathrm{d}, \mathrm{t}} \\
\varepsilon_{\mathrm{s}, \mathrm{t}}
\end{array}\right)+\left(\begin{array}{cc}
\mathrm{b}_{11,1} & \mathrm{~b}_{12,1} \\
\mathrm{~b}_{21,1} & \mathrm{~b}_{22,1}
\end{array}\right)\left(\begin{array}{l}
\varepsilon_{\mathrm{d}, \mathrm{t}-1} \\
\varepsilon_{\mathrm{s}, \mathrm{t}-1}
\end{array}\right)+\ldots+\left(\begin{array}{ll}
\mathrm{b}_{11, \mathrm{n}} & \mathrm{b}_{12, \mathrm{n}} \\
\mathrm{b}_{21, \mathrm{n}} & \mathrm{b}_{22, \mathrm{n}}
\end{array}\right)\left(\begin{array}{c}
\varepsilon_{\mathrm{d}, \mathrm{t}-\mathrm{n}} \\
\varepsilon_{\mathrm{s}, \mathrm{t}-\mathrm{n}}
\end{array}\right)+\ldots
$$


Where $\Delta y_{t}$ is the rate of growth of industrial production, $\Delta p_{t}$ is the rate of growth of the consumer price index, and $\varepsilon_{\mathrm{d}, \mathrm{t}}$ and $\varepsilon_{\mathrm{s}, \mathrm{t}}$ are independent demand and supply shocks, each with a zero mean and a constant variance.

Using the lag operator $\mathrm{L}$ and assuming that

$B_{i}=\left[\begin{array}{ll}b_{11, i} & b_{12, i} \\ b_{21, i} & b_{22, i}\end{array}\right]$, this infinite moving average process can also be written as:

$\left[\begin{array}{c}\Delta \mathrm{y}_{\mathrm{t}} \\ \Delta \mathrm{p}_{\mathrm{t}}\end{array}\right]=\left[\begin{array}{c}\mathrm{b}_{10} \\ \mathrm{~b}_{20}\end{array}\right]+\sum_{\mathrm{i}=0}^{\infty} \mathrm{L}^{\mathrm{i}} \mathrm{B}_{\mathrm{i}}\left[\begin{array}{c}\varepsilon_{\mathrm{d}, \mathrm{t}} \\ \varepsilon_{\mathrm{s}, \mathrm{t}}\end{array}\right]$

Moreover, as in the traditional supply and demand model usually described in economic textbooks, demand shocks only have a temporary effect on output, Bayoumi and Eichengreen introduce a long term restriction into their VAR:

they consider that $\sum_{\mathrm{i}=0}^{\infty} \mathrm{b}_{11, \mathrm{i}} \varepsilon_{\mathrm{d}, \mathrm{t}-\mathrm{i}}=0$.

Since these demand and supply shocks are not observed, the purpose of this methodology is to find a way to recover them from the VAR estimation.

Then the following VAR representations ${ }^{11}$ are estimated:

$\left(\begin{array}{c}\Delta \mathrm{y}_{\mathrm{t}} \\ \Delta \mathrm{p}_{\mathrm{t}}\end{array}\right)=\left(\begin{array}{l}\chi_{10} \\ \chi_{20}\end{array}\right)+\left(\begin{array}{ll}\chi_{11,1} & \chi_{12,1} \\ \chi_{21,1} & \chi_{22,1}\end{array}\right)\left(\begin{array}{l}\Delta \mathrm{y}_{\mathrm{t}-1} \\ \Delta \mathrm{p}_{\mathrm{t}-1}\end{array}\right)+\left(\begin{array}{ll}\chi_{11,2} & \chi_{12,2} \\ \chi_{21,2} & \chi_{22,2}\end{array}\right)\left(\begin{array}{c}\Delta \mathrm{y}_{\mathrm{t}-2} \\ \Delta \mathrm{p}_{\mathrm{t}-2}\end{array}\right)+\ldots+\left(\begin{array}{c}\mathrm{e}_{\mathrm{yt}} \\ \mathrm{e}_{\mathrm{pt}}\end{array}\right)$

Blanchard and Quah (1989) have shown that the VAR residuals are composites of the pure shocks. In fact, the VAR residuals are the one-step ahead forecast error:

$\left[\begin{array}{c}\mathrm{e}_{\mathrm{d}, \mathrm{t}} \\ \mathrm{e}_{\mathrm{s}, \mathrm{t}}\end{array}\right]=\left[\begin{array}{c}\Delta \mathrm{y}_{\mathrm{t}} \\ \Delta \mathrm{p}_{\mathrm{t}}\end{array}\right]-\mathrm{E}_{\mathrm{t}-1}\left[\begin{array}{c}\Delta \mathrm{y}_{\mathrm{t}} \\ \Delta \mathrm{p}_{\mathrm{t}}\end{array}\right]$

From the bivariate moving average process, this can be written $\left[\begin{array}{c}\mathrm{e}_{\mathrm{d}, \mathrm{t}} \\ \mathrm{e}_{\mathrm{s}, \mathrm{t}}\end{array}\right]=\mathrm{B}_{0}\left[\begin{array}{c}\varepsilon_{\mathrm{d}, \mathrm{t}} \\ \varepsilon_{\mathrm{s}, \mathrm{t}}\end{array}\right]$. Consequently, $\left[\begin{array}{c}\mathrm{e}_{\mathrm{d}, \mathrm{t}} \\ \mathrm{e}_{\mathrm{s}, \mathrm{t}}\end{array}\right]\left[\begin{array}{ll}\mathrm{e}_{\mathrm{d}, \mathrm{t}} & \mathrm{e}_{\mathrm{s}, \mathrm{t}}\end{array}\right]=\mathrm{B}_{0}\left[\begin{array}{c}\varepsilon_{\mathrm{d}, \mathrm{t}} \\ \varepsilon_{\mathrm{s}, \mathrm{t}}\end{array}\right]\left[\begin{array}{ll}\varepsilon_{\mathrm{d}, \mathrm{t}} & \varepsilon_{\mathrm{s}, \mathrm{t}}\end{array}\right] \mathrm{B}_{0}^{\prime}$, which can also be written as:

$\left[\begin{array}{cc}\operatorname{var}\left(\mathrm{e}_{\mathrm{d}, \mathrm{t}}\right) & \operatorname{cov}\left(\mathrm{e}_{\mathrm{d}, \mathrm{t}}, \mathrm{e}_{\mathrm{s}, \mathrm{t}}\right) \\ \operatorname{cov}\left(\mathrm{e}_{\mathrm{d}, \mathrm{t}}, \mathrm{e}_{\mathrm{s}, \mathrm{t}}\right) & \operatorname{var}\left(\mathrm{e}_{\mathrm{s}, \mathrm{t}}\right)\end{array}\right]=\mathrm{B}_{0}\left[\begin{array}{cc}\operatorname{var}\left(\varepsilon_{\mathrm{d}, \mathrm{t}}\right) & \operatorname{cov}\left(\varepsilon_{\mathrm{d}, \mathrm{t}}, \varepsilon_{\mathrm{s}, \mathrm{t}}\right) \\ \operatorname{cov}\left(\varepsilon_{\mathrm{d}, \mathrm{t}}, \varepsilon_{\mathrm{s}, \mathrm{t}}\right) & \operatorname{var}\left(\varepsilon_{\mathrm{s}, \mathrm{t}}\right)\end{array}\right] \mathrm{B}_{0}^{\prime}$

\footnotetext{
${ }^{11}$ Note that data used in the analysis presented in sections 3 and 4 are not seasonally adjusted, seasonal dummies were introduced in the VAR estimations.
} 
If the four elements of $\mathrm{B}_{0}$ can be identified, it is possible to recover the supply and demand shocks from the regression residuals. Blanchard and Quah showed that four components of the matrix $\mathrm{B}_{0}$ could be identified by four restrictions. Two of these restrictions are simple normalizations ${ }^{12}$, which define the variance of the shocks $\varepsilon_{\mathrm{d}, \mathrm{t}}$ and $\varepsilon_{\mathrm{s}, \mathrm{t}}: \operatorname{var}\left(\mathrm{e}_{\mathrm{d}, \mathrm{t}}\right)=\mathrm{b}_{11,0}{ }^{2}+\mathrm{b}_{12,0}{ }^{2}$ and $\operatorname{var}\left(\mathrm{e}_{\mathrm{s}, \mathrm{t}}\right)=\mathrm{b}_{21,0}{ }^{2}+\mathrm{b}_{22,0^{2}}$.

A third restriction comes from assuming that demand and supply shocks are orthogonal:

$E\left(e_{1, t} e_{2, t}\right)=b_{11,0} b_{21,0}+b_{12,0} b_{22,0}$.

And the final restriction comes from the long term restriction which states that demand shocks have only a temporary effect on output. ${ }^{13}$

$\left[1-\sum_{\mathrm{i}=0}^{\mathrm{n}} \chi_{22, \mathrm{i}}\right] \mathrm{b}_{11,0}+\sum_{\mathrm{i}=0}^{\mathrm{n}} \chi_{12, \mathrm{i}} \mathrm{b}_{21,0}=0$

Once the elements of the $\mathrm{B}_{0}$ matrix have been identified, the shocks can be recovered in the following way:

$\left[\begin{array}{l}\varepsilon_{\mathrm{d}, \mathrm{t}} \\ \varepsilon_{\mathrm{s}, \mathrm{t}}\end{array}\right]=\left(\mathrm{B}_{0}\right)^{-1}\left[\begin{array}{l}\mathrm{e}_{\mathrm{d}, \mathrm{t}} \\ \mathrm{e}_{\mathrm{s}, \mathrm{t}}\end{array}\right]$.

\section{Description of the data}

In order to apply this methodology, output and price series are needed. Data were obtained from the IMF's International Financial Statistics. The series of prices, denoted below by $\mathrm{p}$, are measured by the consumer price index; while the series of output, denoted below by $\mathrm{y}$, are measured by the industrial production index. ${ }^{14}$ The data are

\footnotetext{
${ }^{12}$ As noted by Bayoumi and Eichengreen (1992), the conventional normalization is that the two variances of the shocks are set equal to unity, which together with the assumption of orthogonality implies $\Sigma=\mathrm{BoBo}^{\prime}$, where $\Sigma$ is the variance-covariance matrix of $\mathrm{e}_{\mathrm{d}, \mathrm{t}}$ and $\mathrm{e}_{\mathrm{s}, \mathrm{t}}$.

13 The reader interested by longest explanations of these restrictions can refer to Blanchard and Quah (1989), Bayoumi and Eichengreen (1992) or Enders (1995).

${ }^{14}$ Note that the results presented below are based on industrial production, which does not cover all sectors of the economy. The industrial production index measures the real output of the electric and gas utilities, manufacturing, and mining industries. Nevertheless, as discussed by Lobo et al. (1999), this choice is pertinent because the industrial sector is highly exposed to international competition due to its high openness. Although it represents a limited share of GDP, manufactured goods account for a considerable proportion of total exports and imports in EU countries (around 75\%). Hence any future extension of the Euro zone is likely to have an important effect on this sector. Moreover, as noted by Hartley and Whitt (2003), cycles in industrial production might be more similar than cycles in other component of output and the use of industrial production rather than GDP avoids the problems with measuring government output that infect the GDP statistics.
} 
quarterly for the period 1993:1-2005:3. ${ }^{15}$ The choice of period and of countries was determined by the availability of the data and excludes the first years of the transition process, which started in 1990 and probably includes the most abrupt structural changes. Nevertheless, the first four quarters are cut off to differentiate $y$ and $p$ on the basis of annual changes.

The countries included in the analysis are: Austria (AUS), Belgium (BEL), Cyprus (CYP), the Czech Republic (CZE), Denmark (DEN), Finland (FIN), France (FRA), Germany (GER), Greece (GRE), Hungary (HUN), Ireland (IRE), Italy (ITA), Lithuania (LIT), Luxembourg (LUX), Malta (MAL), the Netherlands (NET), Norway (NOR), Poland (POL), Portugal (POR), Slovenia (SLA), the Slovak Republic (SLK), Spain (SPA), Sweden (SWE), Switzerland (SWI) and the United Kingdom (UKI). This means that the analysis covers 25 countries, including the 15 initial members of the European Union, 2 members of EFTA (Switzerland and Norway) and 8 new EU members (Cyprus, the Czech republic, Hungary, Lithuania, Malta, Poland, Slovenia and the Slovak Republic). It includes EU countries that are not in the Euro zone and countries bordering on the EU.

Data are not seasonally adjusted ${ }^{16}$ and two lags were used in the VAR estimations. Consequently, the VAR estimations have been performed on the period 1994:3-2005:3. ${ }^{17}$ Seasonal dummies were introduced in the VAR model.

$\Delta y$ measures the variation of the logarithm of industrial production and $\Delta \mathrm{p}$ measures the variation of the logarithm of the consumer price index.

The goal is to compare the shocks striking these countries with those characterizing the Euro zone. The growth rates of the industrial production and of the consumer price index for the Euro zone were computed as the average of the respective growth rates of each of these variables in the 12 Euro zone member countries weighted by the share of each of these countries in the total Euro zone GDP in 2000. These aggregate series for the Euro zone respectively are:

\footnotetext{
${ }^{15}$ Except for Lithuania and Malta where data on industrial production were only available from $1997 \mathrm{Q} 1$. Moreover, the most recent quarterly data available for Malta when data were retrieved were dated on 2005:2 (compared to 2005:3 for the other countries).

${ }^{16}$ Except for Slovenia where data on industrial production were seasonally adjusted.

${ }^{17}$ Except for Lithuania and Malta where, as explained above, data on industrial production were only available from 1997Q1. In these cases, the VAR estimations have been performed from 1998:3 until 2005:3 for Lithuania and until 2005:2 for Malta.
} 


$$
\mathrm{Y}_{\epsilon 12, \mathrm{t}}=\sum_{\mathrm{i}=1}^{12} \mathrm{w}_{\mathrm{i}, 2000} \mathrm{Y}_{\mathrm{i}, \mathrm{t}} \text { where } \mathrm{w}_{\mathrm{i}, 2000}=\frac{\mathrm{GDP}_{\mathrm{i}, 2000}}{\sum_{\mathrm{i}=1}^{12} \mathrm{GDP}_{\mathrm{i}, 2000}}
$$

and

$$
\mathrm{P}_{\epsilon 12, \mathrm{t}}=\sum_{\mathrm{i}=1}^{12} \mathrm{w}_{\mathrm{i}, 2000} \mathrm{P}_{\mathrm{i}, \mathrm{t}} \text { where } \mathrm{w}_{\mathrm{i}, 2000}=\frac{\mathrm{GDP}_{\mathrm{i}, 2000}}{\sum_{\mathrm{i}=1}^{12} \mathrm{GDP}_{\mathrm{i}, 2000}}
$$

where the subscript i denotes one of the 12 Euro zone member countries.

Note that in order to avoid "spurious" results between Euro zone member countries and the whole Euro area, another set of aggregate series was also computed, where the series of each individual Euro zone member countries are not compared to the Euro zone as a whole but to an area made up of all the Euro zone except the country being from the comparison. This method is applied below to all the comparisons made between the Euro zone individual member countries and the Euro zone. By applying this correction, it is possible to ensure that the correlations reflect whether the series for each individual Euro zone member countries are or are not moving in line with that of other Euro zone countries. In fact, as the data used for the Euro zone are the weighted average of data from the member countries which made up the Euro area, a similar pattern would not be a surprise for large Euro zone member countries. Therefore, all the comparison between an individual Euro zone member country and the Euro zone have been made in comparing the data of the individual country with an area made up of all the Euro zone member countries but the country being from the comparison.

Figures 2 and 3 exhibit the average growth rate of industrial production and inflation rate in the Euro area (EUR) and in individual countries. Figure 2 concerns the whole available common sample, while Figure 3 exclusively focuses on the post 2000 period. In these Figures, one can observed that new EU member countries as the Czech Republic, Hungary, Lithuania, Poland and the Slovak Republic are characterized by high average growth rates of their industrial production index. Ireland is the only current Euro area member country which exhibits an industrial production index growing on average at the same pace. Figure 3 also exhibits that, on average, Italy, Portugal, the United Kingdom were struck by negative growth rates of their industrial sector. The comparison between Figure 2 and Figure 3 highlights the decrease in the average inflation rate which has recently been observed in most of the new EU member countries. 
The correlation coefficients of the growth rates of the industrial production index and of the inflation rates between the Euro area and individual countries are presented in Table 1 .

In the column entitled GIP_EUR, the correlation coefficients between the growth rate of the average industrial production index in the Euro area and the growth rate of the industrial production index in the countries whose names are abbreviated in the first column are presented.

In the column entitled GCPI_EUR, the correlation coefficients between the average inflation rate in the Euro area and the inflation rate in the countries whose names are abbreviated in the first column are presented.

These correlation coefficients have been computed on the whole common available sample: 1998:1-2005:2. The levels of significance of these correlation coefficients are presented in brackets. Two stars denoted that the null hypothesis of no linear correlation between the country growth rate of output or price and the Euro area growth rate of output or price can be rejected on the basis of a t-test at $5 \%$ level, while one star denotes that the null hypothesis of no linear correlation between the country growth rate of output or price and the Euro area growth rate of output or price can be rejected on the basis of a t-test at $10 \%$ level. Note that as seasonality can be more prominent in some countries, the similarities in the seasonal pattern could influence the results presented in Table 1.

Moreover, it is important to highlight that in order to avoid a bias in the correlation calculated for the Euro zone member countries, the growth rate of their industrial production index and their inflation rate has not been directly compared with the average growth rates of industrial production and inflation in the Euro zone as a whole but with the average growth rates of industrial production and inflation in an area made up of all the Euro zone member countries but the country being from the comparison, as explained above.

The area denoted "NEW" represents the area made up of the new EU member states whose data on industrial production and prices were available on IMF's International Financial Statistics on-line (which are Cyprus, the Czech Republic, Hungary, Lithuania, Malta, Poland, Slovenia and the Slovak Republic). The average output growth and inflation in this area have been computed with the same methodology as this applied to the Euro zone aggregate series. 


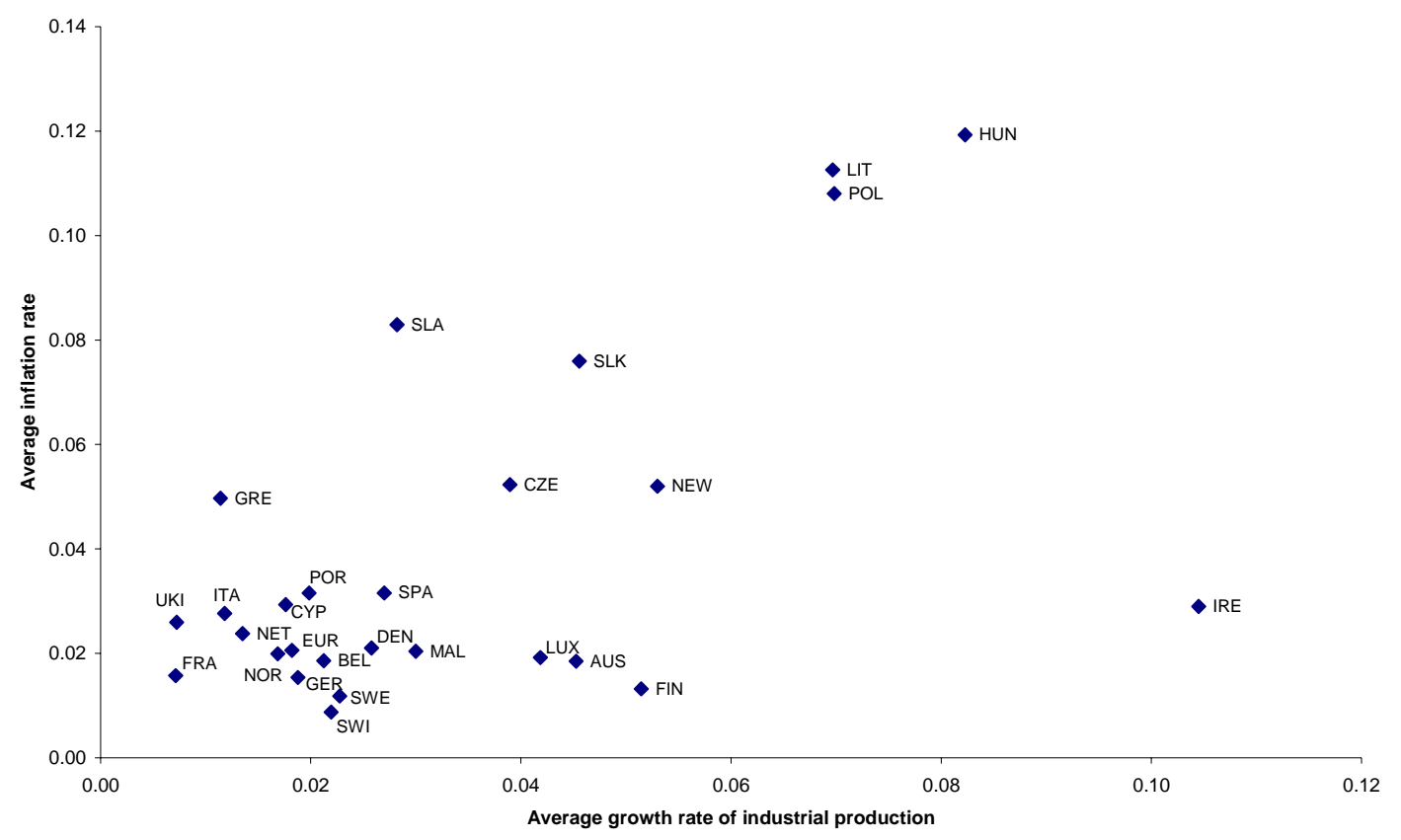

Figure 2. Average inflation and growth rates

(on the period 1994-2005, except for Lithuania and Malta where the available sample was 1998-2005)

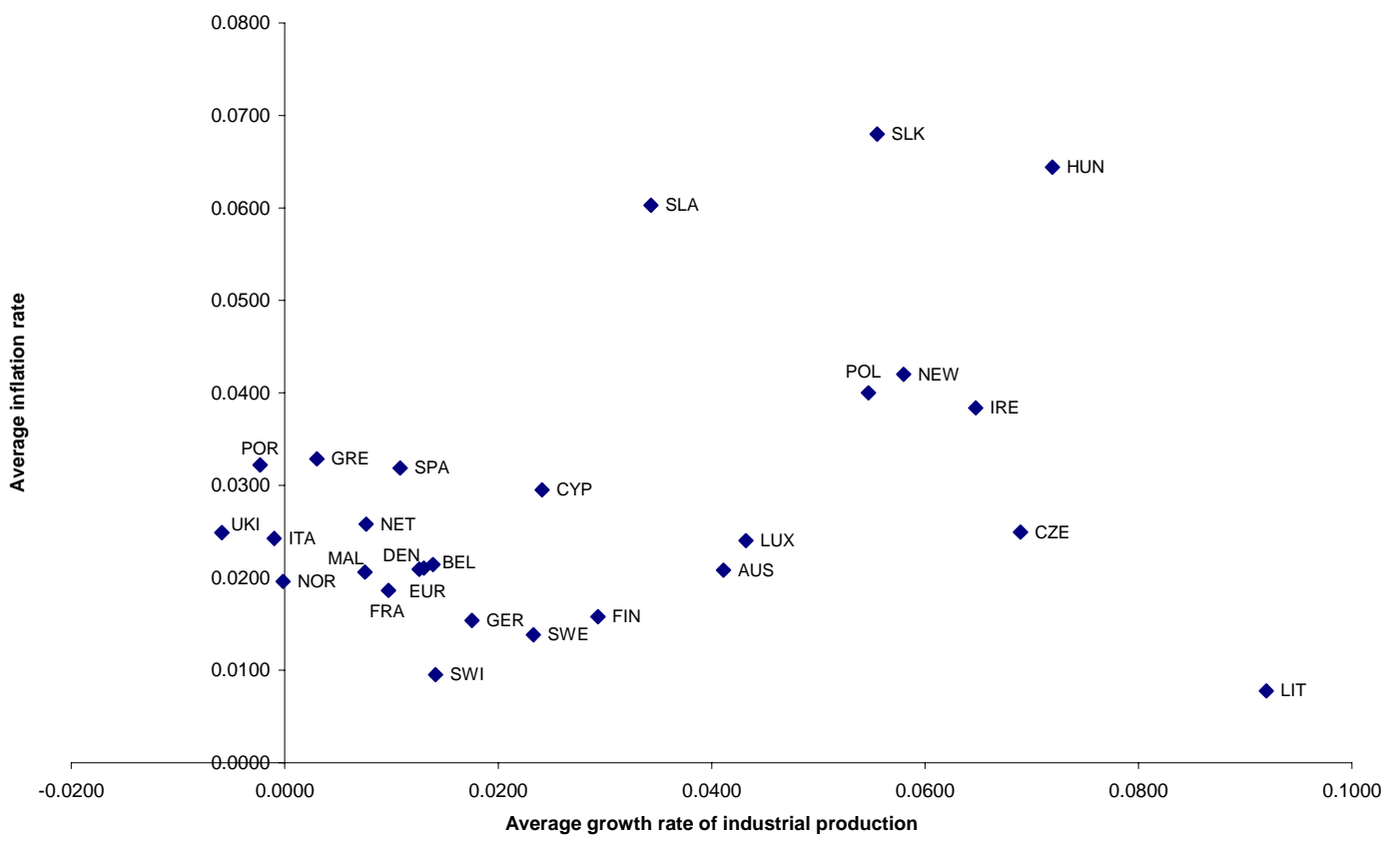

Figure 3. Average inflation and growth rates (on the period 2000-2005) 


\begin{tabular}{|c|c|c|c|c|}
\hline \multicolumn{5}{|c|}{$\begin{array}{c}\text { Correlation coefficients of the growth rate of industrial } \\
\text { production and of the inflation rate between the euro } \\
\text { area and individual countries }\end{array}$} \\
\hline & GIP_EUR & $\mathrm{t}$ & GCPI_EUR & $\mathrm{t}$ \\
\hline AUS & ** 0.90 & (10.32) & ** 0.88 & (9.08) \\
\hline $\mathrm{BEL}$ & ** 0.82 & (7.17) & ** 0.79 & $5.54)$ \\
\hline YP & -0.16 & $(-0.81)$ & ** 0.33 & 1.74) \\
\hline CZE & 0.07 & $\overline{(0.34)}$ & -0.17 & $(-0.88)$ \\
\hline DEN & *夫 0.48 & (2.73) & 0.16 & $(0.84)$ \\
\hline FIN & ** 0.80 & $(6.61)$ & ** 0.42 & $(2.30)$ \\
\hline FRA & ** 0.79 & $(6.36)$ & ** 0.68 & (4.61) \\
\hline GER & ** 0.87 & $(8.89)$ & ** 0.76 & $(5.93)$ \\
\hline GRE & ** 0.76 & $(5.81)$ & -0.01 & $(-0.06)$ \\
\hline HUN & ** 0.83 & $(7.42)$ & ${ }^{\star \star}-0.32$ & $(-1.68)$ \\
\hline IRE & 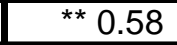 & $(3.52)$ & 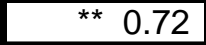 & (5.14) \\
\hline ITA & $\star \star 0.87$ & $(8.76)$ & ** 0.77 & $(5.96)$ \\
\hline LIT & 0.04 & $(0.19)$ & -0.19 & $(-0.96)$ \\
\hline LUX & ** 0.31 & $(1.65)$ & ** 0.88 & $(9.17)$ \\
\hline MAL & ** 0.70 & $(4.92)$ & 0.20 & $(1.04)$ \\
\hline NET & ** 0.76 & $(5.76)$ & ** 0.43 & $(2.37)$ \\
\hline NEW & ** 0.60 & $(3.75)$ & ${ }^{*}-0.27$ & $(-1.40)$ \\
\hline NOR & 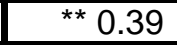 & (2.10) & 0.20 & $(1.02)$ \\
\hline $\mathrm{POL}$ & ** 0.49 & $(2.83)$ & * -0.27 & $(-1.39)$ \\
\hline$\overline{\mathrm{POR}}$ & 0.12 & $(0.59)$ & ** 0.53 & (3.09) \\
\hline SLA & ** 0.63 & (4.09) & 0.22 & (1.10) \\
\hline SLK & ** 0.37 & $(1.96)$ & -0.13 & $(-0.63)$ \\
\hline SPA & ** 0.76 & (5.81) & ** 0.81 & $(7.01)$ \\
\hline SWE & *夫 0.74 & $(5.46)$ & ** 0.70 & $(4.86)$ \\
\hline SWI & ** 0.91 & $(10.87)$ & ** 0.57 & $(3.46)$ \\
\hline UKI & ** 0.80 & $(6.61)$ & 0.01 & $(0.07)$ \\
\hline
\end{tabular}

Table 1

\section{Empirical results}

The Blanchard and Quah methodology permits to identify the 4 elements of $\mathrm{B}_{0}$ and therefore to recover supply and demand shocks from the regression residuals. This methodology has been applied to the data presented above. Once demand and supply shocks are retrieved by this procedure, impulse response functions measuring the propagation of the shocks can be calculated and plotted.

\section{1. "Extracting" demand and supply shocks:}

In this model, shocks with temporary effect on output are interpreted as demand shocks and shocks with permanent effect on output are interpreted as supply shocks. This distinction is embedded in the long run restriction imposed in the estimation procedure but does not permit as such to interpret shocks with permanent impact on output as pure supply shocks and shocks with temporary impact on output as pure demand shocks. 
Actually, in the AD-AS model, there exist two other conditions, which are not predetermined in the empirical model presented above. According to the AD-AS model, positive (negative) demand shocks lead to an increase (decrease) in prices, while positive (negative) supply shocks lead to a decrease (increase) in prices. These conditions are called the "overidentifying" conditions. It is possible to check whether they are fulfilled or not by looking at the estimated impulse-response functions. When they are satisfied, these "overidentifying" conditions help to interpret permanent output disturbances as supply shocks and transitory output disturbances as demand shocks. As these "overidentifying" conditions are not predetermined in the empirical model, the estimated results may lead to responses in price or output which are not in line with the aggregate demand and supply model.

The results are presented in Table 2 and in Figure 4. In the performed estimations, only 13 out of 25 countries respect the "overidentifying" restrictions: Austria, Belgium, Cyprus, the Czech Republic, France, Germany, Ireland, Lithuania, Malta, the Netherlands, Spain, Sweden, and Switzerland. Moreover, the Euro area and the aggregate zone "NEW" made up of the new EU member states included in this analysis also respect the "overidentifying" restrictions. This proportion of countries fulfilling the "overidentifying" restrictions is lower than in previous studies. This may be explained by different elements. Firstly, as stressed by Bayoumi and Eichengreen (1994), the identification procedure explained above breaks down when demand and supply shocks have the same cause. In this case, the estimated aggregate supply disturbance may incorporate the associated effect on aggregate demand. Bayoumi and Eichengreen (1994) show that countries, which heavily depend on raw-material production, fail to satisfy the prediction of a negative price response to permanent disturbances. ${ }^{22}$ Consequently, in the case of energy producers (such as Denmark, Norway and the United Kingdom), it may be difficult to distinguish between the aggregate supply and demand caused by a change in energy prices. Secondly, another example of common cause for demand and supply shocks could be the kind of restructuring observed in some new EU countries: as noted by Burda and Wyplosz (2005), under the central planning regime, much emphasis had been put on producing heavy industry products which were rarely sold outside the Soviet block, the transformation process led to the restructuring of the industrial sector towards producing more industrial tradable goods and to the emergence of the service sector. This transformation led to an increase in wages, which may affect the aggregate demand. Thirdly, output changes are calculated here on the basis of industrial production rather than on the basis of real GDP. Consequently, supply shocks in the agricultural or service sectors will lead to no change in the industrial output but may affect the consumer price index which is the price series included in the analysis. ${ }^{23}$ This effect may be particularly strong for smaller countries (as Luxembourg) which have a less diversified industrial sector.

\footnotetext{
22 These authors explain that "for raw-material producers, positive supply shocks are associated with increases in the relative price of raw-materials (improvements in the terms of trade) and, hence, with positive aggregate demand shocks. For such countries, supply shocks also have aggregate demand effects producing the perverse behavior of prices".

${ }^{23}$ This series was chosen because it is the most frequently used indicator of inflation and because it is easily available.
} 
Though it may be controversial to interpret shocks with a permanent impact on output as supply shocks and shocks with a temporary impact on output as demand shocks in these conditions, this denomination will be kept as it is also used in other studies, see for example Fidrmuc and Korhonen (2003).

Once the supply and demand disturbances have been estimated for each country, the correlation coefficients between these demand shocks and between these supply shocks have been calculated. These correlations were computed on the basis of pairwise samples in order to include all the available data in the comparison. The period used to measure each correlation coefficient are presented in Table 2.

Note that, here again, in order to avoid "spurious" results between Euro zone member countries and the whole Euro zone, individual Euro area member countries were compared to an area made up of all the Euro area member countries but the country being from the comparison. This correction was useful because if, for instance, the German disturbances were compared with the disturbances observed in the Euro zone overall, there might be a high correlation simply because Germany is a large country which makes up a large part of the Euro zone. Therefore, in order to avoid this kind of "spurious" result, Germany was compared with an area made up of all the Euro zone member countries except Germany.

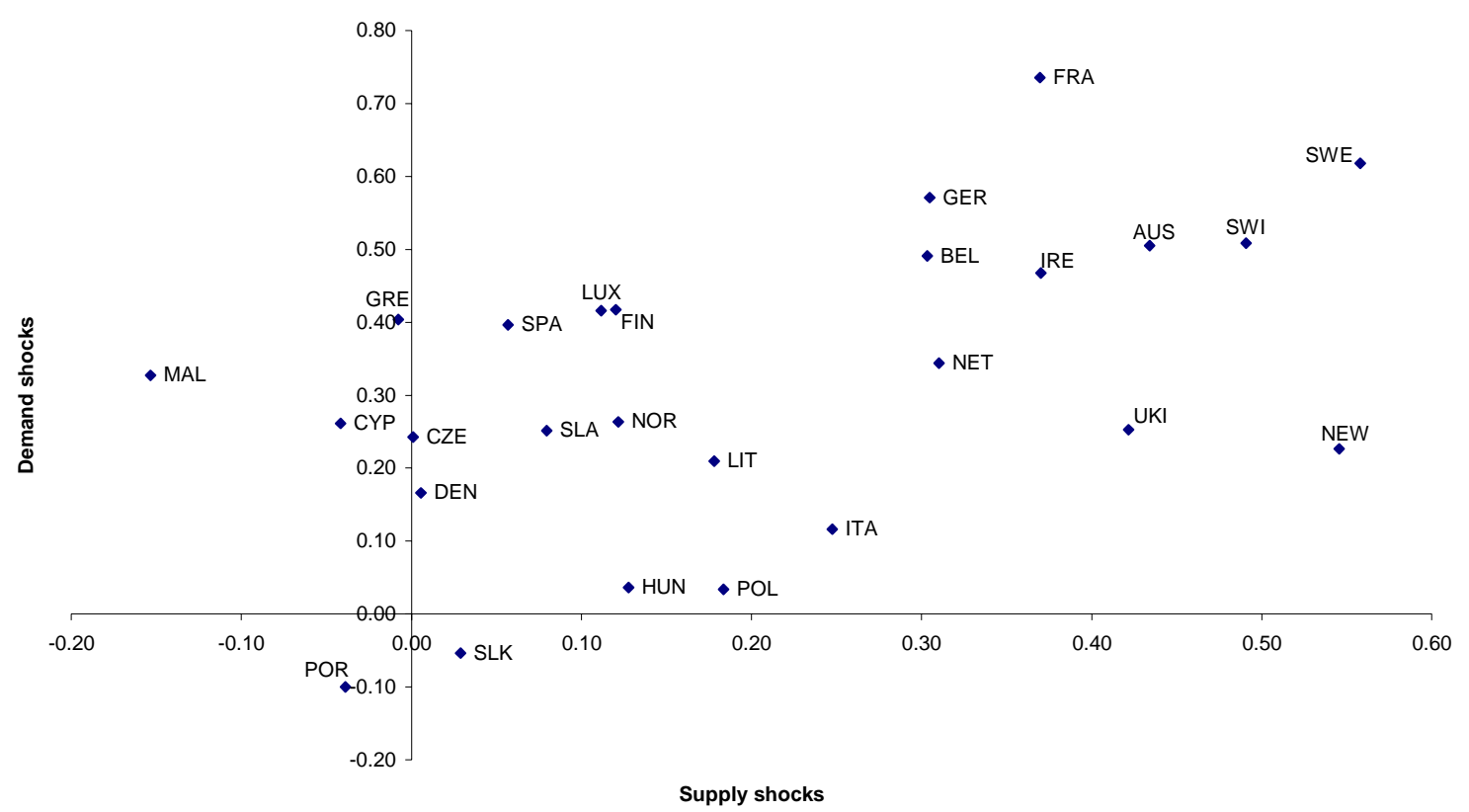

Figure 4

Correlation of specific-country demand shocks with Euro zone demand shocks and of specific-country supply shocks with Euro zone supply shocks.

The coordinates of the points depicted in Figure 4 are presented in Table 2. Moreover, the significance levels of these correlation coefficients are presented in brackets. It can be noted that even if some negative correlations are displayed in Figure 4 and in Table 2, 
none of them can be treated as significantly different from zero on the basis of a significance level for one sided tests at $5 \%$ or at $10 \%$. It is also important to bear in mind that correlation coefficient which is not significantly different from zero does not necessarily mean that there is no relation between these series, but that these series are not strongly linearly related.

The results presented in Table 2 and in Figure 4 show that some heterogeneity exists even among the demand and supply shocks observed in Euro zone member countries. Moreover, the supply disturbances observed in the whole area made up of the new EU member states seem quite well correlated with the supply disturbances observed in the whole Euro zone. In fact, the supply shocks observed in the area called "NEW" seem more strongly correlated with supply shocks observed in the Euro zone than supply shocks observed in each of the new European member countries are. This close correlation of Euro zone shocks with the shocks in an area made up of new European member states can be explained by the fact that country specific-shocks endured by some new EU member states are damped as they are potentially counterbalanced by shocks of opposite signs in other new EU member countries. Moreover, for the same reason, aggregate data may follow a more similar pattern than country-specific data.

\begin{tabular}{|c|c|c|c|c|c|}
\hline \multicolumn{6}{|c|}{ Correlation of demand and supply shocks in the euro area } \\
\hline countries & period & demand dis & bances & supply dis & ances \\
\hline$\overline{A U S}$ & 94Q3-05Q3 & ${ }^{* *} 0.51$ & $(4.45)$ & ${ }^{* \star} 0.43$ & (3.51) \\
\hline$\overline{\mathrm{BEL}}$ & 94Q3-05Q3 & $\star \star 0.49$ & $(4.24)$ & $\star \star 0.30$ & (2.19) \\
\hline CYP & 94Q3-05Q3 & ${ }^{\star \star} 0.26$ & (1.84) & -0.04 & $(-0.27)$ \\
\hline$\overline{\mathrm{CZE}}$ & 94Q3-05Q3 & $\star \star 0.24$ & $(1.69)$ & 0.00 & $(0.01)$ \\
\hline DEN & 94Q3-05Q3 & 0.17 & (1.12) & 0.01 & $(0.04)$ \\
\hline FIN & 94Q3-05Q3 & $\star \star 0.42$ & (3.31) & 0.12 & (0.80) \\
\hline FRA & 94Q3-05Q3 & ${ }^{\star \star} 0.74$ & (10.49) & ${ }^{\star \star} 0.37$ & (2.81) \\
\hline GER & 94Q3-05Q3 & ${ }^{\star \star} 0.57$ & (5.56) & $\star \star 0.30$ & $(2.20)$ \\
\hline GRE & 94Q3-05Q3 & ${ }^{* \star 0} 0.40$ & (3.17) & -0.01 & $(-0.05)$ \\
\hline HUN & 94Q3-05Q3 & 0.04 & $(0.24)$ & 0.13 & $(0.85)$ \\
\hline IRE & 94Q3-05Q3 & ${ }^{\star \star} 0.47$ & (3.93) & $\star \star 0.37$ & (2.81) \\
\hline ITA & 94Q3-05Q3 & 0.12 & $(0.77)$ & $\star \star 0.25$ & $(1.73)$ \\
\hline$\overline{\text { LIT }}$ & 98Q3-05Q3 & 0.21 & (1.14) & 0.18 & (0.96) \\
\hline LUX & 94Q3-05Q3 & ${ }^{\star \star} 0.42$ & (3.30) & 0.11 & $(0.74)$ \\
\hline MAL & 98Q3-05Q2 & ${ }^{\star \star} 0.33$ & (1.90) & -0.15 & $(-0.82)$ \\
\hline NET & 94Q3-05Q3 & $\star \star 0.34$ & $(2.56)$ & $\star \star 0.31$ & $(2.25)$ \\
\hline$\overline{N E W}$ & 98Q3-05Q2 & 0.23 & (1.24) & $\star \star 0.55$ & (4.04) \\
\hline NOR & 94Q3-05Q3 & $\star \star \star 0.26$ & $(1.85)$ & 0.12 & $(0.81)$ \\
\hline POL & 94Q3-05Q3 & 0.03 & $(0.22)$ & 0.18 & $(1.25)$ \\
\hline POR & 94Q3-05Q3 & -0.10 & $(-0.66)$ & -0.04 & $(-0.25)$ \\
\hline SLA & 94Q3-05Q3 & $\star \star 0.25$ & $(1.76)$ & 0.08 & $(0.53)$ \\
\hline SLK & 94Q3-05Q3 & -0.05 & $(-0.35)$ & 0.03 & (0.19) \\
\hline SPA & 94Q3-05Q3 & ${ }^{\star *} 0.40$ & (3.09) & 0.06 & $(0.37)$ \\
\hline$\overline{\text { SWE }}$ & 94Q3-05Q3 & $\star * 0.62$ & (6.56) & 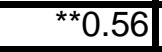 & (5.31) \\
\hline SWI & 94Q3-05Q3 & $\star * 0.51$ & (4.49) & ${ }^{\star \star} 0.49$ & (4.24) \\
\hline UKI & 94Q3-05Q3 & ${ }^{\star \star 0} 0.25$ & $(1.77)$ & ${ }^{\star \star 0} 0.42$ & (3.36) \\
\hline
\end{tabular}

Table 2 
The comparison of these results with those presented in other papers is not easy because the analyses differ in the periods and in the data taken into consideration. Even if some similarities can be detected, the results generally appear as being not strongly robust among studies. The analyses on this topic, mentioned above, point clearly that, as observed here, shocks in some new European member countries are quite well correlated with Euro zone shocks. In fact, shocks in some new EU member countries are as well correlated with Euro zone shocks as shocks from current Euro zone member countries are. Like previous studies on this issue, the results presented above show that there are considerable variations among the new EU member states in the extent to which their demand and supply disturbances match those of the Euro zone. This reflects the huge diversity between these countries.

Nevertheless, the comparison with previous results highlights that the value of correlation coefficients quite often differs depending on sample period or data used to measure inflation and output growth. In the appendix, Table 3 highlights this diversity.

These differences could also be partly explained by the fact that the synchronization of the shocks could be endogenous as claimed by Frankel and Rose (1996). The reasoning behind their assertion is the following: the participation in a currency union eliminates the exchange rate uncertainties among the member countries and therefore, boosts trade among these countries. Closer international integration tends to increase the covariance of country-specific demand shocks (by the spread of changes in the preferences) as well as the covariance of country-specific supply shocks (by the spread of change in productivity). But this view has been contested -see for example Krugman (1993)-: closer integration tends also to raise the degree of specialization if each country tends to produce and export goods and services in which it has a comparative advantage. These two opposite views could also explain why analyses made on different sample may change the results. Moreover as demand and supply shocks may differently affect the various sectors of the economy, the results based on real GDP data could differ from the results based on industrial production.

The method used to measure demand and supply shocks as well as the correlations of demand and supply shocks observed in the Euro zone member countries and in some neighboring countries with those observed in the Euro zone have been presented above.

The impulse response functions trace the effect of a one-time shock, to demand or supply, on the current and future values of the industrial production growth rate and on the current and future value of inflation.

The examination of impulse response function is interesting firstly because, as explained above, it allows to interpret permanent output disturbances as supply shocks and transitory output disturbances as demand shocks when the so called "overidentifying" restrictions are fulfilled; secondly the examination of impulse response function allows to observe the effects on output and prices of a one-time shock to demand or supply. These effects are presented below. 
The propagation of shocks in the Euro zone as a whole and in the new EU member states is presented below. ${ }^{24}$

The results about the propagation of the shocks in the Euro zone and in the new EU member states clearly highlight that adjustment to demand and supply disturbances is faster in the Euro zone member countries than in the new EU member states and that output and price in the latter countries are more sensitive to demand and supply shocks. This result is consistent with the findings of other authors, see for example: Frenkel and Nickel (2002) and (2005a) and Firdmurc and Korhonen (2003).

Figures 5 and 6 represent the adjustments of output growth and inflation to demand and supply disturbances. In order to aid comparison, the graphs for each response function have been depicted with the same scale. Moreover, these responses have been calculated from estimations based on the same sample for the two groups of countries: from the beginning of the existence of the Euro area to the end of the common sample period: 1999:1-2005:2.

The first graph in Figure 5 and in Figure 6 show that in the long run, demand disturbances have no impact on output growth which corresponds to the restriction imposed in the estimation procedure.

The comparison between these responses clearly highlights that the responses to supply and demand disturbances are larger in the new European member countries than in the Euro area and that their speed of adjustment is lower. The higher responses to supply and demand disturbances in the group of new European member countries could be explained by the fact that these countries have recently been characterized by higher average inflation rates as shown in Figures 2 and 3: higher average rate of price change being usually associated with higher inflation variability. ${ }^{25}$ Consequently, a unit demand or supply shock may lead to higher changes in inflation in the event of higher average inflation: on the supply side, a unit shock may lead to higher change in expected inflation; on the demand side, a larger change in expected inflation may create a larger change in real interest rate). Moreover, on the demand side, new European countries may be characterized by higher propensity to consume due to a larger share of households with low income. The slower speed of adjustment in the new European member countries may also be due to several factors: firstly, a positive demand shock may take more time to die out in countries which could be characterized by a higher propensity to consume; secondly, some people argue that automatic stabilizers could be weaker in the new European member states. ${ }^{26}$

\footnotetext{
${ }^{24}$ For the sake of brevity, the presentation of the shock propagation has been restricted to the whole Euro zone and to the group of new European member countries. This choice was also motivated by the fact that some countries do not fulfill the "overidentifying" restrictions, as mentioned above. Note that some individual countries show responses to shocks which are not perfectly in line with the aggregate responses to shocks of their "belonging group". This could be explained by the fact that in aggregate response high responses may be counterbalanced by low responses.

${ }^{25}$ See, for example, Logue and Willett (1976).

${ }^{26}$ See, for example, G. Szapary, Deputy President of the National Bank of Hungary: http://www.euro50.org/past/2002/Szapary.doc
} 
Accumulated Response to Structural One S.D. Innovations in the Euro area
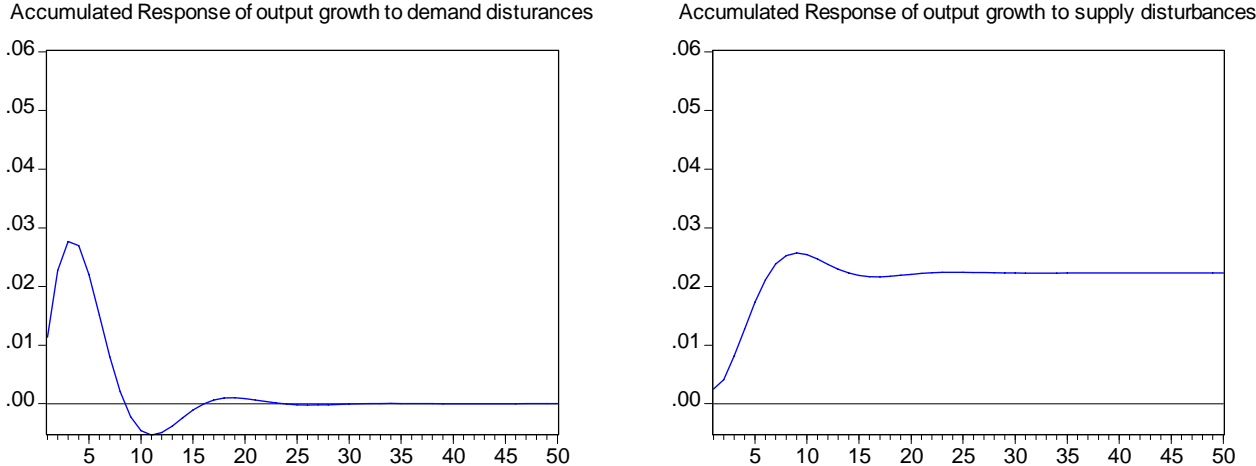

Accumulated Response of inflation to demand disturbances Accumulated Response of inflation to supply disturbances
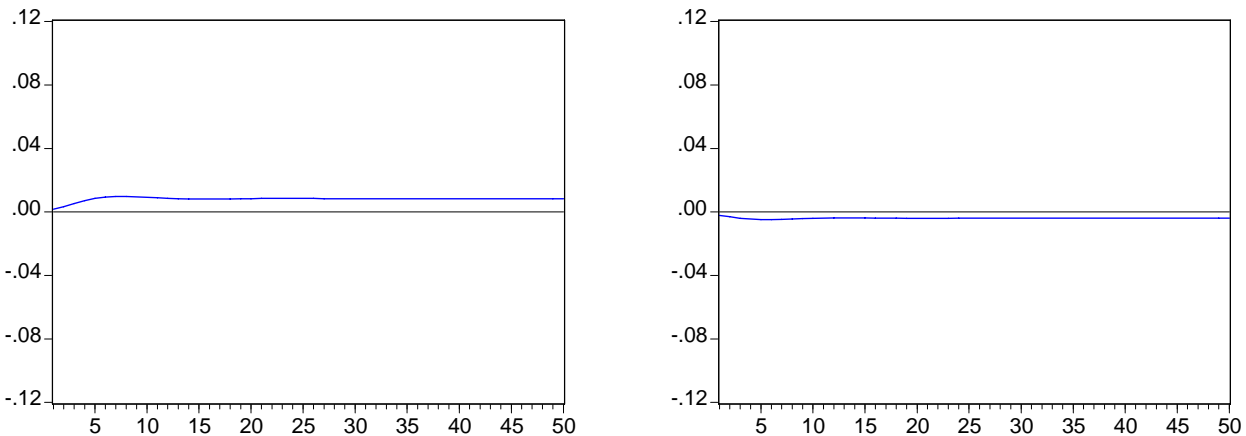

Figure 5

Accumulated Response to Structural One S.D. Innovations in new European member countries

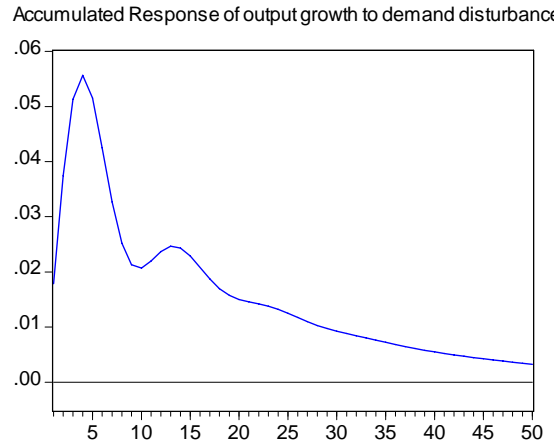

Accumulated Response of output growth to supply disturbances

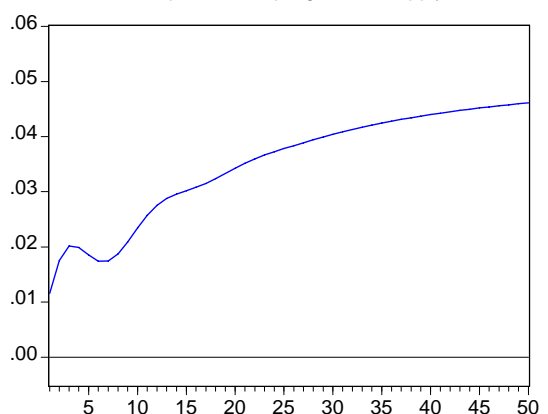

Accumulated Response of inflation to demand disturbances
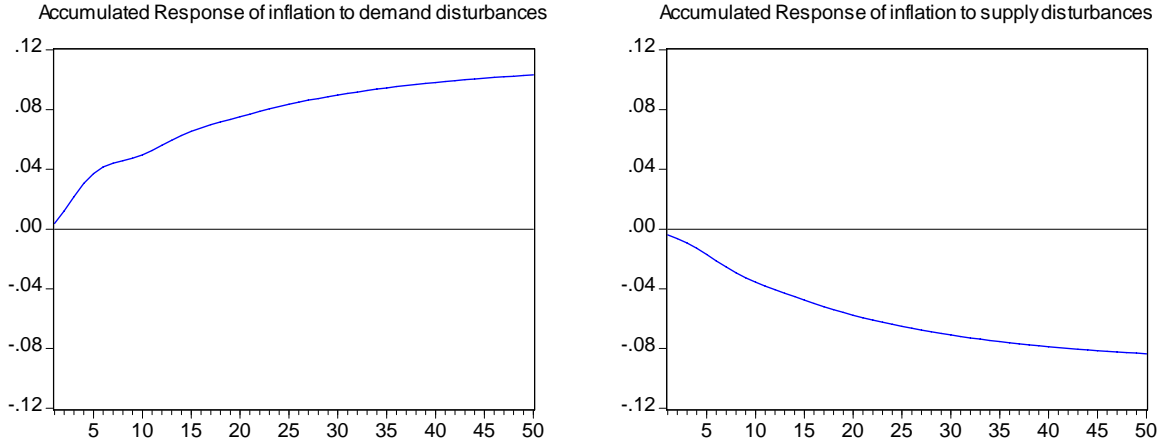

Figure 6 


\section{Conclusion}

This analysis has shed some light on the similarities between new entrants and other EU countries. It seems that shocks in non Euro zone European countries are at least as well correlated with the Euro area shocks as shocks in some current members of the Euro area. Consequently, the fears, that large welfare losses could be suffered by these countries - if the latter joined in the Euro zone - due to the asymmetry of their shocks with those observed in the Euro zone, seem overstated.

Even if the correlation coefficients presented in different studies on this topic differ, the findings presented above broadly confirm the similarities found in previous studies (e.g. in Korhonen and Fidrmuc (2001), Fidrmuc and Korhonen (2003), Frenkel and Nickel $(2005 \mathrm{a}$ and $\mathrm{b})$ ). The results presented above show that there are considerable variations among the new EU member states in the extent to which their demand and supply disturbances match those of the Euro zone, which reflects the huge diversity between these countries. Nevertheless, as explained above, demand and supply shocks in some new European member countries seem as well correlated with shocks striking the Euro area shocks as demand and supply shocks in some current Euro zone countries are.

Moreover, the results presented above confirm that the high correlations found between large Euro zone member countries and the averages for the Euro zone in earlier studies are not spurious: the disturbances observed in large Euro zone countries are well correlated with the disturbances observed in other Euro zone countries.

Of course, the degree of shock synchronization is only one of the elements that has or will be taken into due consideration by each individual country before deciding to be or not member of a currency union. Other adjustment mechanisms may compensate shock asymmetries and countries struck by rather asymmetric shocks may therefore decide to participate in a monetary union, whereas countries hit by similar shocks may decide to stay out. Nevertheless, everything else being equal, shocks synchronization reduces the cost of relinquishing its exchange rate. 


\section{References}

Altavilla C. (2004), "Do EMU Members Share the Same Business Cycles?”, Journal of Common Market Studies, Vol. 42, No.5, pp. 869-896.

Ballabriga F., M. Sebastian and J. Valles (1999), "European Asymmetries", Journal of International Economics, Vol. 48, pp. 233-253.

Bayoumi, T. (1994), “A Formal Model of Optimum Currency Areas”, IMF Staff Papers, Vol.41, No.4, pp. 537-554.

Bayoumi T. and B. Eichengreen (1992), "Shocking Aspects of European Monetary Unification", NBER working paper No.3949.

Bayoumi T. and B. Eichengreen (1994), "One Money or Many? Analyzing the Prospects for Monetary Unification in Various Parts of the World", Princeton Studies in International Finance, No. 76.

Bayoumi T., B. Eichengreen and P. Mauro (1999), "On Regional Monetary Arrangements for ASEAN", working paper presented at the Conference on Exchange Rate Regimes in Emerging Market Economies.

Bayoumi T. and P. Mauro (2001), "The Suitability of ASEAN for a Regional Currency Arrangement", The World Economy, pp. 933-954.

Blanchard O. and D. Quah (1989), "The Dynamic Effects of Aggregate Demand and Supply Disturbances", American Economic Review Vol. 79, pp. 655-673.

Boone L. and M. Maurel (1999), "An Optimal Currency Area Perspective of the EU Enlargement to the CEECs", CEPR working paper No. 2119.

Burda M. and Ch. Wyplosz (2005), "Macroeconomics: a European Text", Oxford University Press, $4^{\text {th }}$ edition.

De Grauwe P. (2003a), "Economics of Monetary Union”, Oxford University Press.

De Grauwe P. (2003b), "The Euro at Stake? The Monetary Union in an Enlarged Europe", CESifo Economics Studies, Vol. 49, pp. 103-121.

Enders W. (1995), “Applied Econometric Time Series”, John Wiley.

Fidrmuc J. and I. Korhonen (2003), "Similarity of Supply and Demand Shocks between the Euro Area and the CEECs", Economic Systems, Vol 27, pp. 313-334.

Fidrmuc J. and I. Korhonen (2006), "Meta-analysis of the business cycle correlation between the Euro area and the Ceecs", CESifo working paper $n^{\circ} 1693$.

Frankle J. and A. Rose (1996), "The endogeneity of the optimum currency area criteria", NBER working paper 5700. Reprinted in Swedish Economy Policy Review 4 (1997): 487-512. Published: The Economic Journal, Vol. 108, no. 449 (July 1998): 1009-1025.

Frenkel M. and C. Nickel (2002), "How Symmetric Are the Shocks and the Shock Adjustment Dynamics Between the Euro Area and Central and Eastern European Countries?" IMF working paper WP/02/222.

Frenkel M. and C. Nickel (2005a), "How Symmetric are the Shocks and the Shocks Adjustment Dynamics between the Euro Area and Central and Eastern European Countries?", Journal of Common Market Studies, Vol. 43, No.1, pp. 53-74.

Frenkel M. and C. Nickel (2005b), "New European Union Members on their Way to Adopting the Euro: An Analysis of Macroeconomic Disturbances", Global Finance Journal, Vol. 15, pp. 303-320.

Funke M. (1997), "The Nature of Shocks in Europe and in Germany", Economica Vol. 64, pp. 461-469. 
Hartley P. and J. Whitt (2003), "Macroeconomic fluctuations: Demand or supply, permanent or temportary", European Economic Review 47, pp. 61-94.

Korhonen I. and J. Fidrmuc (2001), "Similarity of Supply and Demand Shocks between the Euro Area and the Accession Countries", in Focus on Transition 2/2001, Oesterreichische National Bank.

Krugman P. (1993), "Integration, specialization and adjustment”, NBER wp n 4559.

Lobo R., M. Lopez and J. Caralt. (1999), "Specialization in Europe and Asymmetric Shocks: Potential Risks of EMU”, working paper, Universitat de Barcelona.

Logue D. and T. Willett (1976), "A Note on the Relation between the Rate and Variability of Inflation", Economica, 43, pp.151-158.

Mongelli F. P. (2002), "New Views on the Optimum Currency Area Theory: What is EMU Telling Us?”, European Central Bank, working paper No.138.

Mundell (1961), “A Theory of Optimum Currency Areas”, American Economic Review Vol. 51.

Wyplosz C. (2001), “A Monetary Union in Asia? Some European Lessons”, mimeo, Reserve Bank of Australia.

Zhang Y., G. Wan (2005), China's Business Cycles: perspectives from an AD-AS model”, Asian Economic Journal, vol. 19, n4. 


\section{Appendix:}

\begin{tabular}{|c|c|c|c|c|c|c|c|c|}
\hline Author(s) & $\begin{array}{l}\text { Frenkel and Nickel (1992) and } \\
\text { (2005b) the disturbances observ } \\
\text { compared to those observed in F } \\
\text { Italy rather than to those observe }\end{array}$ & $\begin{array}{l}\text { (2005a) [in Frenkel and Nickel } \\
\text { ved in each country are } \\
\text { France, in Germany and in } \\
\text { ed in the Euro Area] }\end{array}$ & $\begin{array}{l}\text { Fidmurc and Korhonen (2003) } \\
\text { Norway and Switzerland, are p } \\
\text { Fidmurc (2001)] }\end{array}$ & $\begin{array}{l}\text { [the same results, excluding } \\
\text { oresented in Korhonen and }\end{array}$ & Funke (1997) & & Bayoumi and Eichengreen & (1992) \\
\hline Sample period & $\begin{array}{l}\text { 1993-2001; quarterly data on rea } \\
\text { Comparison with Germany, Fran } \\
\text { presented. }\end{array}$ & $\begin{array}{l}\text { al GDP and GDP deflator. } \\
\text { ince and Italy are also }\end{array}$ & $\begin{array}{l}\text { beginning of the } 90 \text { s to } 2000: 4 ; \\
\text { or industrial production index a } \\
\text { producer price index. Compari } \\
\text { France are also presented. }\end{array}$ & $\begin{array}{l}\text {; quarterly data on real GDP } \\
\text { and GDP deflator or } \\
\text { ison with Germany and }\end{array}$ & $\begin{array}{l}\text { 1964-1992; annual data on } \\
\text { deflator. }\end{array}$ & real GDP and GDP & $\begin{array}{l}\text { 1962-1988; annual data on } \\
\text { deflator. }\end{array}$ & real GDP and GDP \\
\hline Countries & $\begin{array}{l}\text { correlation of demand shocks } \\
\text { with Euro area-11 countries }\end{array}$ & $\begin{array}{l}\text { correlation of supply shocks } \\
\text { with Euro area-11 countries }\end{array}$ & \begin{tabular}{|l|} 
correlation of demand shocks \\
with the Euro area
\end{tabular} & $\begin{array}{l}\text { correlation of supply shocks } \\
\text { with the Euro area }\end{array}$ & $\begin{array}{l}\text { correlation of demand } \\
\text { shocks with Germany }\end{array}$ & $\begin{array}{l}\text { correlation of supply } \\
\text { shocks with Germany }\end{array}$ & $\begin{array}{l}\text { correlation of demand } \\
\text { shocks with Germany }\end{array}$ & $\begin{array}{l}\text { correlation of supply } \\
\text { shocks with Germany }\end{array}$ \\
\hline AUS & -0.04 & 0.18 & $\begin{array}{r}0.08 \\
\end{array}$ & $\begin{array}{r}0.38 \\
\end{array}$ & $\begin{array}{r}0.34 \\
\end{array}$ & $\begin{array}{r}0.62 \\
\end{array}$ & n.a. & n.a. \\
\hline $\mathrm{BEL}$ & 0.94 & 1.00 & 0.00 & 0.53 & 0.18 & 0.40 & 0.33 & 0.61 \\
\hline CYP & n.a. & n.a. & n.a. & n.a. & n.a. & n.a. & n.a. & n.a. \\
\hline CZE & 0.21 & 0.05 & -0.15 & 0.04 & n.a. & n.a. & n.a. & n.a. \\
\hline DEN & 0.39 & 0.47 & 0.13 & 0.18 & 0.24 & 0.31 & 0.39 & 0.59 \\
\hline FIN & -0.10 & 0.54 & 0.06 & 0.30 & -0.01 & 0.22 & n.a. & n.a. \\
\hline FRA & 0.35 & 0.74 & 0.30 & 0.69 & 0.14 & 0.26 & 0.35 & 0.54 \\
\hline GER & 0.31 & 0.62 & 0.18 & 0.66 & 1.00 & 1.00 & 1.00 & 1.00 \\
\hline GRE & -0.01 & -0.10 & -0.01 & 0.05 & 0.22 & 0.21 & 0.19 & 0.14 \\
\hline HUN & 0.12 & 0.73 & 0.25 & 0.46 & n.a. & n.a. & n.a. & n.a. \\
\hline IRE & n.a. & n.a. & 0.13 & -0.14 & 0.16 & -0.04 & -0.08 & -0.06 \\
\hline ITA & 0.55 & 0.76 & 0.57 & 0.52 & -0.28 & -0.05 & $\begin{array}{c}0.17 \\
\end{array}$ & 0.23 \\
\hline LIT & n.a. & n.a. & \begin{tabular}{l|}
-0.49 \\
\end{tabular} & -0.11 & n.a. & n.a. & n.a. & n.a. \\
\hline LUX & n.a. & n.a. & n.a. & n.a. & 0.54 & 0.14 & n.a. & n.a. \\
\hline MAL & n.a. & n.a. & n.a. & n.a. & n.a. & n.a. & n.a. & n.a. \\
\hline NET & -0.58 & -0.07 & 0.04 & 0.47 & 0.47 & 0.51 & 0.17 & 0.59 \\
\hline NEW & -0.28 & -0.16 & n.a. & n.a. & n.a. & n.a. & n.a. & n.a. \\
\hline NOR & n.a. & n.a. & -0.1 & 0.25 & 0.12 & 0.06 & n.a. & n.a. \\
\hline $\mathrm{POL}$ & 0.22 & -0.69 & \begin{tabular}{c|}
0.28 \\
\end{tabular} & 0.08 & n.a. & n.a. & n.a. & n.a. \\
\hline POR & 0.11 & -0.18 & \begin{tabular}{l|l}
0.09 \\
\end{tabular} & 0.45 & 0.22 & 0.14 & 0.21 & 0.21 \\
\hline SLA & -0.15 & 0.66 & -0.18 & 0.15 & n.a. & n.a. & n.a. & n.a. \\
\hline SLK & -0.43 & 0.18 & -0.05 & 0.05 & n.a. & n.a. & n.a. & n.a. \\
\hline SPA & 0.03 & 0.42 & 0.16 & 0.22 & $\begin{array}{l}0.1 \\
\end{array}$ & $\begin{array}{l}-0.25 \\
\end{array}$ & $\begin{array}{c}-0.07 \\
\end{array}$ & 0.31 \\
\hline SWE & 0.3 & 0.60 & \begin{tabular}{l|l}
0.09 \\
\end{tabular} & 0.24 & -0.09 & $\begin{array}{l}0.35 \\
\end{array}$ & n.a. & n.a. \\
\hline SWI & n.a. & n.a. & 0.00 & 0.16 & n.a. & n.a. & n.a. & n.a. \\
\hline UKI & -0.22 & 0.68 & \begin{tabular}{|c|}
-0.13 \\
\end{tabular} & 0.21 & 0.31 & 0.45 & 0.16 & 0.11 \\
\hline
\end{tabular}

Table 3. Comparisons from other studies. 


\section{CESifo Working Paper Series}

(for full list see www.cesifo-group.de)

1816 Gottfried Haber and Reinhard Neck, Sustainability of Austrian Public Debt: A Political Economy Perspective, October 2006

1817 Thiess Buettner, Michael Overesch, Ulrich Schreiber and Georg Wamser, The Impact of Thin-Capitalization Rules on Multinationals' Financing and Investment Decisions, October 2006

1818 Eric O’N. Fisher and Sharon L. May, Relativity in Trade Theory: Towards a Solution to the Mystery of Missing Trade, October 2006

1819 Junichi Minagawa and Thorsten Upmann, Labor Supply and the Demand for Child Care: An Intertemporal Approach, October 2006

1820 Jan K. Brueckner and Raquel Girvin, Airport Noise Regulation, Airline Service Quality, and Social Welfare, October 2006

1821 Sijbren Cnossen, Alcohol Taxation and Regulation in the European Union, October 2006

1822 Frederick van der Ploeg, Sustainable Social Spending in a Greying Economy with Stagnant Public Services: Baumol's Cost Disease Revisited, October 2006

1823 Steven Brakman, Harry Garretsen and Charles van Marrewijk, Cross-Border Mergers \& Acquisitions: The Facts as a Guide for International Economics, October 2006

1824 J. Atsu Amegashie, A Psychological Game with Interdependent Preference Types, October 2006

1825 Kurt R. Brekke, Ingrid Koenigbauer and Odd Rune Straume, Reference Pricing of Pharmaceuticals, October 2006

1826 Sean Holly, M. Hashem Pesaran and Takashi Yamagata, A Spatio-Temporal Model of House Prices in the US, October 2006

1827 Margarita Katsimi and Thomas Moutos, Inequality and the US Import Demand Function, October 2006

1828 Eytan Sheshinski, Longevity and Aggregate Savings, October 2006

1829 Momi Dahan and Udi Nisan, Low Take-up Rates: The Role of Information, October 2006

1830 Dieter Urban, Multilateral Investment Agreement in a Political Equilibrium, October 2006 
1831 Jan Bouckaert and Hans Degryse, Opt In Versus Opt Out: A Free-Entry Analysis of Privacy Policies, October 2006

1832 Wolfram F. Richter, Taxing Human Capital Efficiently: The Double Dividend of Taxing Non-qualified Labour more Heavily than Qualified Labour, October 2006

1833 Alberto Chong and Mark Gradstein, Who's Afraid of Foreign Aid? The Donors' Perspective, October 2006

1834 Dirk Schindler, Optimal Income Taxation with a Risky Asset - The Triple Income Tax, October 2006

1835 Andy Snell and Jonathan P. Thomas, Labour Contracts, Equal Treatment and WageUnemployment Dynamics, October 2006

1836 Peter Backé and Cezary Wójcik, Catching-up and Credit Booms in Central and Eastern European EU Member States and Acceding Countries: An Interpretation within the New Neoclassical Synthesis Framework, October 2006

1837 Lars P. Feld, Justina A.V. Fischer and Gebhard Kirchgaessner, The Effect of Direct Democracy on Income Redistribution: Evidence for Switzerland, October 2006

1838 Michael Rauscher, Voluntary Emission Reductions, Social Rewards, and Environmental Policy, November 2006

1839 Vincent Vicard, Trade, Conflicts, and Political Integration: the Regional Interplays, November 2006

1840 Erkki Koskela and Mikko Puhakka, Stability and Dynamics in an Overlapping Generations Economy under Flexible Wage Negotiation and Capital Accumulation, November 2006

1841 Thiess Buettner, Michael Overesch, Ulrich Schreiber and Georg Wamser, Taxation and Capital Structure Choice - Evidence from a Panel of German Multinationals, November 2006

1842 Guglielmo Maria Caporale and Alexandros Kontonikas, The Euro and Inflation Uncertainty in the European Monetary Union, November 2006

1843 Jan K. Brueckner and Ann G. Largey, Social Interaction and Urban Sprawl, November 2006

1844 Eytan Sheshinski, Differentiated Annuities in a Pooling Equilibrium, November 2006

1845 Marc Suhrcke and Dieter Urban, Are Cardiovascular Diseases Bad for Economic Growth?, November 2006

1846 Sam Bucovetsky and Andreas Haufler, Preferential Tax Regimes with Asymmetric Countries, November 2006 
1847 Luca Anderlini, Leonardo Felli and Andrew Postlewaite, Should Courts always Enforce what Contracting Parties Write?, November 2006

1848 Katharina Sailer, Searching the eBay Marketplace, November 2006

1849 Paul De Grauwe and Pablo Rovira Kaltwasser, A Behavioral Finance Model of the Exchange Rate with Many Forecasting Rules, November 2006

1850 Doina Maria Radulescu and Michael Stimmelmayr, ACE vs. CBIT: Which is Better for Investment and Welfare?, November 2006

1851 Guglielmo Maria Caporale and Mario Cerrato, Black Market and Official Exchange Rates: Long-Run Equilibrium and Short-Run Dynamics, November 2006

1852 Luca Anderlini, Leonardo Felli and Andrew Postlewaite, Active Courts and Menu Contracts, November 2006

1853 Andreas Haufler, Alexander Klemm and Guttorm Schjelderup, Economic Integration and Redistributive Taxation: A Simple Model with Ambiguous Results, November 2006

1854 S. Brock Blomberg, Thomas DeLeire and Gregory D. Hess, The (After) Life-Cycle Theory of Religious Contributions, November 2006

1855 Albert Solé-Ollé and Pilar Sorribas-Navarro, The Effects of Partisan Alignment on the Allocation of Intergovernmental Transfers. Differences-in-Differences Estimates for Spain, November 2006

1856 Biswa N. Bhattacharyay, Understanding the Latest Wave and Future Shape of Regional Trade and Cooperation Agreements in Asia, November 2006

1857 Matz Dahlberg, Eva Mörk, Jørn Rattsø and Hanna Ågren, Using a Discontinuous Grant to Identify the Effect of Grants on Local Taxes and Spending, November 2006

1858 Ernesto Crivelli and Klaas Staal, Size and Soft Budget Constraints, November 2006

1859 Jens Brøchner, Jesper Jensen, Patrik Svensson and Peter Birch Sørensen, The Dilemmas of Tax Coordination in the Enlarged European Union, November 2006

1860 Marcel Gérard, Reforming the Taxation of Multijurisdictional Enterprises in Europe, "Coopetition" in a Bottom-up Federation, November 2006

1861 Frank Blasch and Alfons J. Weichenrieder, When Taxation Changes the Course of the Year - Fiscal Year Adjustments and the German Tax Reform 2000/2001, November 2006

1862 Hans Jarle Kind, Tore Nilssen and Lars Sørgard, Competition for Viewers and Advertisers in a TV Oligopoly, November 2006 
1863 Bart Cockx, Stéphane Robin and Christian Goebel, Income Support Policies for PartTime Workers: A Stepping-Stone to Regular Jobs? An Application to Young LongTerm Unemployed Women in Belgium, December 2006

1864 Sascha O. Becker and Marc-Andreas Muendler, The Effect of FDI on Job Separation, December 2006

1865 Christos Kotsogiannis and Robert Schwager, Fiscal Equalization and Yardstick Competition, December 2006

1866 Mikael Carlsson, Stefan Eriksson and Nils Gottfries, Testing Theories of Job Creation: Does Supply Create Its Own Demand?, December 2006

1867 Jacques H. Drèze, Charles Figuières and Jean Hindriks, Voluntary Matching Grants Can Forestall Social Dumping, December 2006

1868 Thomas Eichner and Marco Runkel, Corporate Income Taxation of Multinationals and Unemployment, December 2006

1869 Balázs Égert, Central Bank Interventions, Communication and Interest Rate Policy in Emerging European Economies, December 2006

1870 John Geweke, Joel Horowitz and M. Hashem Pesaran, Econometrics: A Bird's Eye View, December 2006

1871 Hans Jarle Kind, Marko Koethenbuerger and Guttorm Schjelderup, Taxation in TwoSided Markets, December 2006

1872 Hans Gersbach and Bernhard Pachl, Cake Division by Majority Decision, December 2006

1873 Gunther Schnabl, The Evolution of the East Asian Currency Baskets - Still Undisclosed and Changing, December 2006

1874 Horst Raff and Michael J. Ryan, Firm-Specific Characteristics and the Timing of Foreign Direct Investment Projects, December 2006

1875 Jukka Pirttilä and Håkan Selin, How Successful is the Dual Income Tax? Evidence from the Finnish Tax Reform of 1993, December 2006

1876 Agnieszka Stążka, Sources of Real Exchange Rate Fluctuations in Central and Eastern Europe - Temporary or Permanent?, December 2006

1877 Xavier Calsamiglia, Teresa Garcia-Milà and Therese J. McGuire, Why do Differences in the Degree of Fiscal Decentralization Endure?, December 2006

1878 Natacha Gilson, How to be Well Shod to Absorb Shocks? Shock Synchronization and Joining the Euro Zone, December 2006 